\title{
ONE RURAL, TWO VISIONS - ENVIRONMENTAL ISSUES AND IMAGES ON RURAL AREAS IN PORTUGAL
}

\author{
Elisabete Figueiredo ${ }^{1}$
}

Received 9 September 2008; Accepted 16 December 2008

Abstract: In recent years rural areas, specially the most peripheral and remote ones, have become increasingly perceived and identified as spaces of outstanding environmental quality. This relatively new function of the rural, while widely recognized both socially and institutionally, is to some extent strange to local residents to whom the natural resources and the environmental aspects are mainly perceived from an utilitarian perspective. The exteriority of the measures and policies to preserve rural environment tends to place remote rural areas in a new subaltern position. Correspondingly, the social and institutional construction of rural areas as environmental reserves tends to create a new rural-urban dichotomy which may have important repercussions in terms of the future directions of rural development processes. We aim to discuss the abovementioned aspects, based on empirical evidence from two Portuguese rural areas. We conclude that there are two different visions about the rural - the rural to visit and the rural to live - conveyed respectively by the urban residents and the State and by the local inhabitants.

Keywords: remote rural areas; rural environment; rural-urban dichotomy; rural development

Resumo: Nos últimos anos, as áreas rurais, particularmente as mais remotas e periféricas, têm vindo crescentemente a ser percepcionadas e identificadas como espaços de elevada qualidade ambiental. Se por um lado esta nova função das áreas rurais é amplamente reconhecida a nível social e institucional, por outro lado, constitui-se como estranha para os residentes locais, para quem os recursos naturais e as questões ambientais são apreendidos a partir de uma perspectiva essencialmente utilitarista. A exterioridade das medidas e políticas que visam preservar o ambiente rural tende a colocar as áreas rurais remotas numa nova posição de subalternização. Paralelamente, a construção social e institucional das áreas rurais como reservas ambientais tende a criar uma nova dicotomia rural-urbano, que pode ter importantes consequências em termos das direcções futuras dos processos de desenvolvimento local. Com base na evidência empírica recolhida em duas áreas rurais portuguesas, procuramos debater os aspectos antes mencionados. Concluímos que existe, em termos de representações sociais sobre o rural, um rural para visitar e um rural para viver. Estas representações são, no primeiro caso, propriedade das populações urbanas e do Estado e, no segundo caso, dos habitantes locais.

\footnotetext{
1 Assistant Profesor Elisabete Figueiredo, PhD. Unit of Social, Legal and Political Sciences, University of Aveiro, 3810-193 Aveiro, Portugal; e-mail: elisa@ua.pt
} 
Palavras-Chave: áreas rurais remotas; ambiente rural; dicotomia rural-urbano; desenvolvimento rural.

\section{Introduction}

In recent years rural areas, specially the most peripheral and remote ones, have become increasingly perceived and identified as spaces of outstanding environmental quality. Underlying the aforementioned aspects is the growing valorisation of the environment in contemporary societies as well as the social movements of demand and consumption of environmental goods and amenities.

This relatively new function of the rural, while widely recognized both socially and institutionally, is to some extent strange to local residents to whom the natural resources and the environmental aspects are mainly perceived from an utilitarian perspective. The exteriority of the measures and policies to preserve rural environment tends to place remote rural areas in a new subaltern position. Correspondingly, the social and institutional construction of rural areas as environmental reserves tends to create a new rural-urban dichotomy. This is no longer the old dichotomy that opposed the traditional (rural) to the modern (urban) and the agricultural activities to the industrial activities, but a new opposition based on different rural and urban perceptions about rurality, rural environment as well as about economic development.

If one can state that in some central European countries (such as Great-Britain, Germany or France) the social demand and consumption of the countryside as environmental and natural space is a well documented phenomenon, in Portugal it is only in an emergent phase. On the other hand, most Portuguese rural areas can be described as declining areas, consequence of the major social and economic transformations they suffer during last decades, as well as in result of the development policies and measures implemented by the country in the same period. In spite of that (or exactly because of that) nowadays those areas seem to fulfil the desires and needs of urban populations in terms of environmental quality and in terms of cultural and social authenticity. Although bearing in mind the fact that there is a variety of rural areas, characterized by different features, opportunities and constraints (e.g. Kayser, 1990; Cavaco, 1993; Mormont, 1994b) one can refer that the areas most demanded and consumed are the remote rural ones, which means, precisely the areas undergoing a major process of economic and social decline.

While important for non-rural populations, the maintenance of a certain rurality or of a certain rural environment does not have the same significance for local people. In this sense, the existence of two different visions, of a duality, in terms of perceptions in view of the same territory can be observed.

Based on empirical evidence from two Portuguese rural areas (the Natural Park of Montesinho and the Serra da Freita), we discuss the abovementioned aspects and we bring to the fore that the visions of the residents and visitors of both areas studied are not coincident, causing the emergence of two parallel rural universes: the rural to visit and the rural to live. We also emphasise that this duality of visions is culturally determined, not only by individuals' socioeconomic characteristics, but also by the different levels of development that both categories of actors experience in everyday life.

\section{Rural Areas as Objects of Consumption - the role of environmental issues}

The difficulty of defining rural and rurality is well documented by rural sociology literature since decades ago (e.g. Kayser, 1990, Mormont, 1990; Melo, 1992, Cavaco, 1993; Jollivet, 1994 and 1997; Figueiredo, 2003a). Most of the existing typologies to classify rural areas refer to a conception of rural and rurality that clearly opposes them to the urban, both in spatial and in social terms and this opposition is still "very clear in most countries" of Europe (Jollivet, 1994: 6). In a recent work on rural-urban differences in Europe, Shucksmith et al. (2006: 3) state that "despite critiques, rural and urban continued to be portrayed, if not as polar opposites, then at least as distinctly different entities". Of course that in the actual globalization era it is impossible 
to deny the reciprocal influences between rural and urban contexts, but the definition of rural and rurality still involves remoteness from urban areas in a variety of ways. Nevertheless the social and economic transformations of rural areas across western countries suggest the emergency of a new set of relations between town and country and also of a new rural-urban opposition.

Although the decline of rural areas was pointed out by many authors in the late eighties and early nineties ${ }^{2}$ and announced as a general crisis of the rural world, the diversity of situations of being rural is immense. Shucksmith et al. (2006) also point out this diversity drawing attention to the fact that many rural areas in Europe are now growing faster than urban regions, while others experience a declining situation. In addition, the authors affirm that the social and economic processes "underlying these diverse trends are not fully understood, however one key element is the increasingly global penetration of local markets. Rural areas (...) may be particular prone to exploitation by international capital, leading to increased dependency and peripherality" (Shucksmith et al., 2006: 6). Particularly vulnerable to these processes are remote rural areas of southern Europe. In 1994, Mormont also defended the idea of a diverse rural Europe making a distinction between peripheral rural Europe and central rural Europe and referring that what separates them is, first of all, their relative proximity and economic integration in the European core. Central rural Europe belongs, of course, to the industrial nucleus of Europe, with an intensive and highly productive agricultural activity. These rural spaces are strongly integrated in the commercial and industrial circuits and hold populations that Mormont calls very urbanised. On the other hand, peripheral rural Europe is constituted by areas suffering several handicaps related both to natural conditions (soil, climate, etc) and to geographical and cultural remoteness to industrial and economic growth poles. However, like Shucksmith et al., also Mormont (1994b) pointed out that this was a very concise and inaccurate typology since peripheral and remote areas can as well be found in central Europe and in southern European countries there are rural areas that have experienced a great economic expansion.

The peripheral rural areas of Europe suffer, for decades, of a continual abandonment in terms of its populations and activities as well as of a persistent neglecting in terms of public policies and measures. At the same time these areas are increasingly seen as offering a better quality of life, representing an outstanding value in terms of environmental and natural quality. Although these attributes are not new in the social and political discourses about the rural and rurality, as for instance Woods (2003) demonstrates ${ }^{3}$, they gained some strength in recent years, following the increase of social concern and valorisation of the environment in contemporary societies. Woods (2003: 272) emphasises that "nature has long been a keystone in the social construction of rurality. The discursive dualisms of nature-society and nature-civilisation have historically informed the separation of town and country in literature, art, government policy and lay discourse and have feed moral geographies which by aligning rurality with nature have elevated the countryside as pure, nobler and more treasured space than the city".

Remote rural areas represent increasingly the paradigm of the reencounter of society with nature and they are, as well, progressively understood as "moral and cultural reserves" (Chamboredon, 1980). Consequently rurality is no longer represented as synonym of a concrete condition of opposition and marginalization vis-à-vis modernisation processes, but rather as a synonym of modernity (or post-modernity) expressed through the discovery and valorisation of the differences, of the authentic and genuine (e.g. Joaquim, 1994). Rural areas tend to acquire "in parallel with their condition of cultural symbols, an extremely environmental symbology (...). Such a function, as much material as symbolic is quite evident in the institutional proposals for the rural areas of most European countries" (Figueiredo, 2008A: 161-162), following the statement of EEC in 1988 that "rural areas are not only places where people live and work for at the same time they play vital functions for society as a whole" (EEC, 1998: 2). This also demonstrates the multifunctional character attributed today to rural areas in which the

\footnotetext{
2 See, among others, the works of Comolet (1990); Gilg (1991); King (1992); Sainteny (1992); Mormont (1994a); Pernet (1994); Ramos-Real (1995); Jollivet (1997).

${ }^{3}$ On this subject one can also see the works of Macnaghten and Urry (1998); Cudworth (2003) and Figueiredo (2002, 2003, 2008a, 2008b).
} 
environmental issues assume special relevance ${ }^{4}$ mainly for recreation, tourism and leisure activities for non local populations, particularly urban". As Luginbuhl (1991: 28) refer "to the eyes of townsmen this appropriation [of the rural] means a deep transformation of the social representations of the rural space, that gradually loses its utilitarian and productive function". ${ }^{6}$ Or as in the obligatory and pioneer words of Howard Newby (1985: 14) "the continuing emphasis on the 'primitive virtues' of rural life can be regarded as part of an occasionally despairing search for authenticity in a modern, meretricious world. It reflects (...) our dissatisfaction with life in towns and cities (...). Instead there remains the belief that urban life is a superficial and temporary substitute for the real thing" - the rural. In consequence the countryside often becomes a symbolic 'middle-way' "between the 'wildness' of unmodified nature, and the artificial built environs of the town and city" and in that sense "Western attitudes to the countryside have been shaped by a response known as the 'pastoral'. Within this 'myth' agricultural life is seen as more wholesome, spiritually rewarding and 'natural' than urban life" (Cudworth, 2003: 118). In accordance with Mathieu and Jollivet (1989) there is currently an increasing social - mainly urban - identification between the rural, the nature and the environment. This identification is also deeply rooted on a vision of the rural as idyllic space that is, accordingly with Halfacree $(1993,1995)$, a hegemonic social representation ${ }^{7}$.

The representation of rural space as pure nature ${ }^{8}$, as scenery of distraction, rest and regeneration for urban populations originates the increasing frequency, demand and consumption of the rural by non local populations and creates the conditions to its commodification $^{9}$. These processes can produce important effects in the social and economic rural contexts, namely conflicts among the various actors (and particularly between residents and visitors) in presence. The conflicts occur mainly due to the discrepancy of visions, desires and needs between the non local and the local populations. In addition, the exteriority of the rural environment's valorisation processes, above all expressed by the urban populations and materialised by the State in several programmes, measures and actions regarding the rural, is a central issue in the conflicting situations. This kind of double external vision towards the rural, frequently not incorporating the needs and aspirations of rural residents, is a central aspect in the formation of a new rural-urban dichotomy. It is also a vision relatively strange to rural inhabitants for whom the environment and natural elements are above all a resource. It is also a lived and daily used environment, then assuming to local populations a statute of vulgarity. The exceptionality attributed to rural space and its environmental features by external actors and agents reveals different legitimacies as well as important social inequalities, since the external legitimacies tend to overlay those of local populations in the uses of space and natural elements. These different legitimacies are based not only in several and different social and institutional visions about the environment, the rural and nature, but equally (and perhaps more significantly) in the historical (and somewhat chronic) irreconcilable vision of the relation between environmental issues and rural development aspects.

\footnotetext{
${ }^{4}$ The majority of authors consulted point out three main functions of rural areas nowadays: ensuring food production in an efficient way; preserving the landscape and the rural environment, and maintaining the rural areas as a recreation and leisure resource for non local populations.

${ }^{5}$ We use the term urban populations as we use the term rural populations, in a sense too much all-inclusive and vague. This means that we are aware of the fact that there is not only one type or urban or rural populations, but that under that designation there are several situations and conditions.

${ }^{6}$ On the topic of the emptying of rural areas of its productive function due to its valorisation as environmental and cultural reserves see, among others, the works of Mormont (1984); Chamboredon (1985); Macnaghten and Urry (1998); Figueiredo (2003a, 2008a).

About the rural idyll as well as the diversity of representations and social images of the rural, see the works of Halfacree (1993, 1995, and 1997); Bell (1997) and Phillips et al (2001).

${ }^{8}$ We have been speaking of rural nature in the sense that it is represented nowadays, i.e., a nature that is thought pure, for opposition to the one existing in the cities. In this regard O'Hear (1998) draws our attention to the fact that nowadays nature invokes a powerful and quasi-religious aura. This author refers that nature is a myth that is necessary to deconstruct, since as the natural world is in continuous transformation, it is relatively arbitrary to appoint one moment as the pure, normal or natural state. Underlying the theme of nature's purity it is the definition of artificial, i.e., of everything that is increased or modified by human action. It is in the misunderstanding that the rural represents a non artificialized or very little transformed nature, that lies the social identification of the environment as nature and as countryside. See in relation to this topic also Pinet (1984); Gilg (1991); Lowe (1992); Dunlap and Beus (1992a, 1992b and 1994); Mormont (1994a) and Jollivet (1994, 1997)

${ }^{9}$ On the transformation of the rural space in a marketable and consumption object see Macnaghten and Urry (1998), Butler, Hall and Jenkins (1998) and Butler and Hall (1998).
} 


\section{Methodology and Case Studies}

In order to address the abovementioned central role of environmental issues in the social construction of the rural and rurality, as well as the emergence of a new rural-urban dichotomy, we carried out a study ${ }^{10}$ in two Portuguese rural areas that can be characterized as remote and peripheral - the Natural Park of Montesinho (NPM) and Serra da Freita (SF). We applied 721 questionnaires to a sample of inhabitants and visitors of both areas, as well as 35 structured interviews to the political and administrative entities, such as the presidents of the parishes, the presidents of the municipalities, the natural park manager and the administrators of local development associations.

In each area, the residents' samples (by quotas) were constructed on the basis of several criteria: number of inhabitants in each parish; sex, age, literacy level, economic activity and profession. The visitors' samples (also using the quota sample procedures) were constructed based on the most visited places within both areas. Thus, we inquired 220 inhabitants and 150 visitors in NPM area and 201 residents and 150 visitors in SF area. Univariate and bivariate analysis of the data collected were performed in order to measure the associations and the differences within and between residents and visitors' categories. At the same time, the interviews were analysed through content analysis techniques.

As we can see in figure 1, Natural Park of Montesinho is located on the northern region of Portugal and Serra da Freita in the central region. In spite of geographically distant both areas share many social, economic and demographic features. However, while NPM is a legally protected area, Serra da Freita does not possess any legal status of protection. This constitutes an important difference between the two areas studied, since while NPM is institutionally (and socially) recognized as an extraordinary rural space and environment, SF is an ordinary rural area. In spite of that as we will see in the next section, this distinction is not significant in terms of different rurality and environment perceptions between residents and visitors.

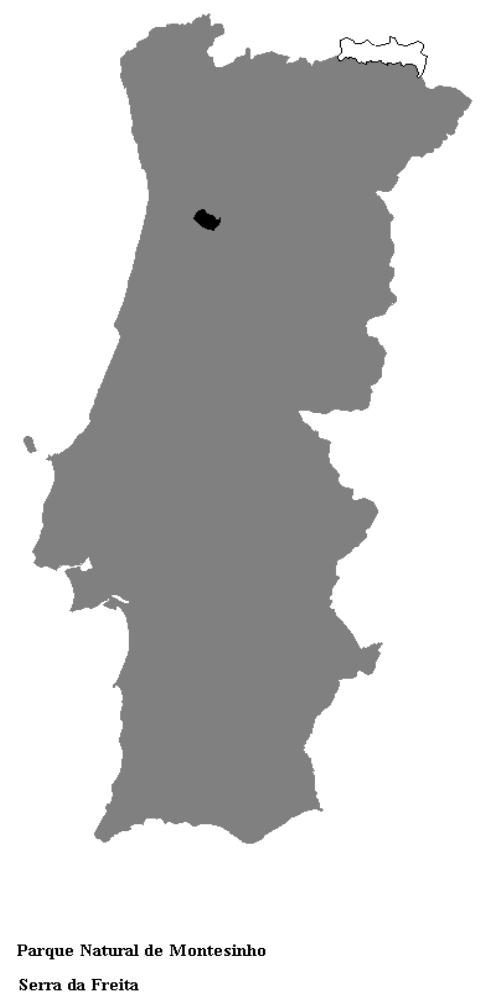

Fig 1. Location of Natural Park of Montesinho and Serra da Freita

10 This research was conducted in the context of a PhD programme about the role of environmental issues in rural development policies and strategies in Portugal (Figueiredo, 2003a). 
Both areas can be characterised as remote and marginalized rural spaces in the Portuguese context. In fact, both areas are characterised by strong losses of population (more than $50 \%$ since 1960), by the existence of an aged population as well as by a small percentage of economically active individuals. The predominant economic activities are agriculture and cattle breeding, although often combined with other activities, such as industry and services. In spite of this situation of social and economic decline and in spite of the fact that there is an evident lack of services and infrastructures related with tourism activities, both areas receive a large number of visitors every year. Thus, in both areas is visible the existence of some opposite perceptions and visions about rurality and environment.

Regarding the characteristics of the residents and visitors we inquired on both areas, the first aspect to be pointed out is the existence of obvious and marked differences between the two categories in terms of age, literacy level, income and levels of materialism ${ }^{11}$ (figures 2 to 5).

Thus, visitors are younger, with higher levels of literacy, with higher levels of income and they also stand out for defending more post-materialistic values than the inhabitants in both areas. These features are particularly evident among the visitors of NPM area.

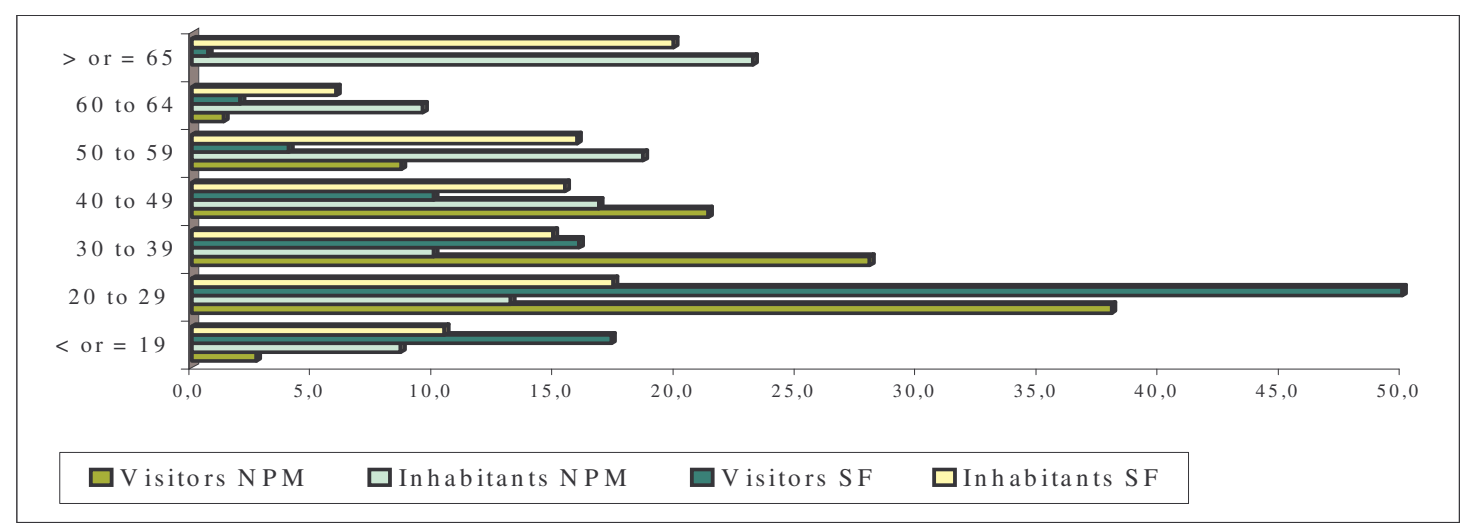

Fig 2. Age structure of residents and visitors inquired in NPM and SF (\%)

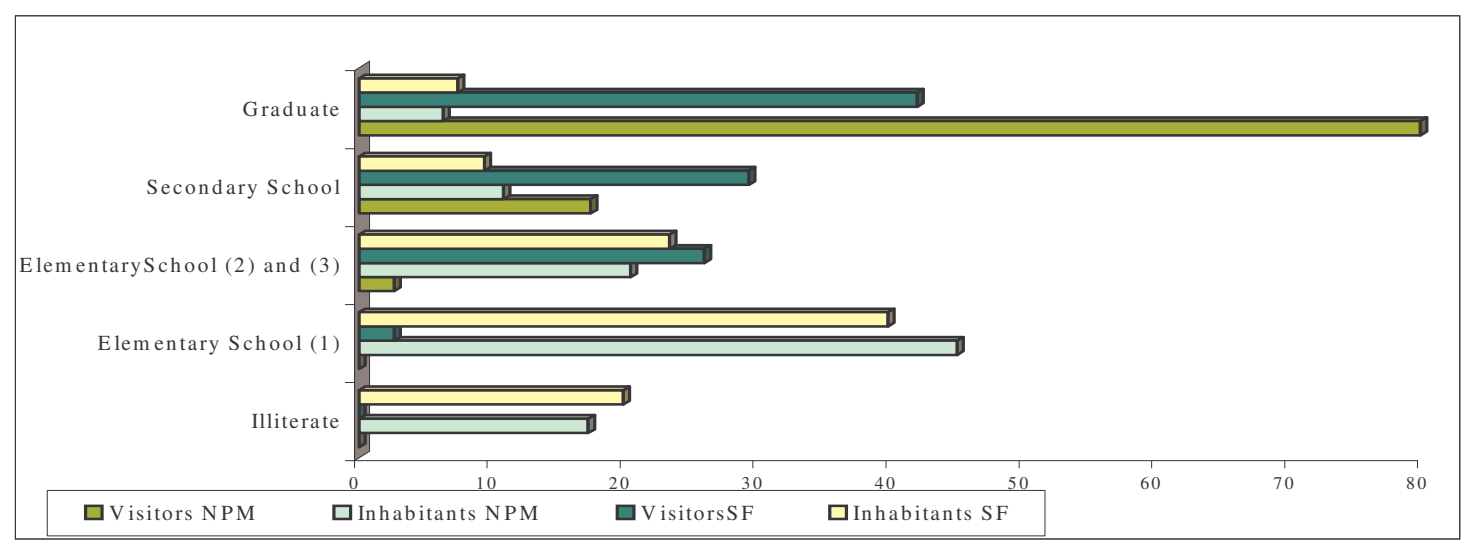

Fig 3. Levels of literacy of residents and visitors of NPM and SF (\%)

Visitors of both areas have predominantly urban origin, although we can observe a more geographical dispersion among NPM visitors (in fact the majority come from Lisbon and its metropolitan area). Visitors of SF are mainly from the closer cities and urban areas. These geographical differences can be explained by the type of recreation and leisure activities carried

\footnotetext{
${ }^{11}$ An index of materialism/post-materialism was constructed based on a set of questions relative to the adhesion to a certain type of values. The forms of the questions and the answer's categories used are an adaptation of what it is proposed by Inglehart (1990). By materialistic values we designated a set of values such as the emphasis on the economical growth, the importance given to the existence of a strong army at the national level, the importance given to the physical and material security. By post-materialistic values we intend to designate a set of values, including the importance given to the freedom of speech, the importance of the environmental protection, the emphasis on peace as a goal for the entire world, etc.
} 
out within the two areas, since NPM visitors stayed, in general, in this area for more than three days $(61,3 \%)$ and SF visitors only spend a few hours on this rural space (94\%). Additionally, while NPM visitors frequent this rural area searching for a closer contact with nature, observation of wild animals and plants as well as for peace and rest, SF visitors perform more active leisure and recreation actions, such as radical sports activities (e.g. cross-country, rafting, canoeing) as well as picnics. Certainly these differences are also be explained by the fact that NPM is a protected area, thus offering diverse opportunities for tourism, recreation and leisure. Moreover, few visitors in both areas referred as motivations for visiting these rural areas aspects related with rural life itself, which demonstrate that visitors prefer landscapes where human action is not immediately perceived, confirming the thesis of the rural idyll as well as the general social perception of rural areas as back to nature locales.

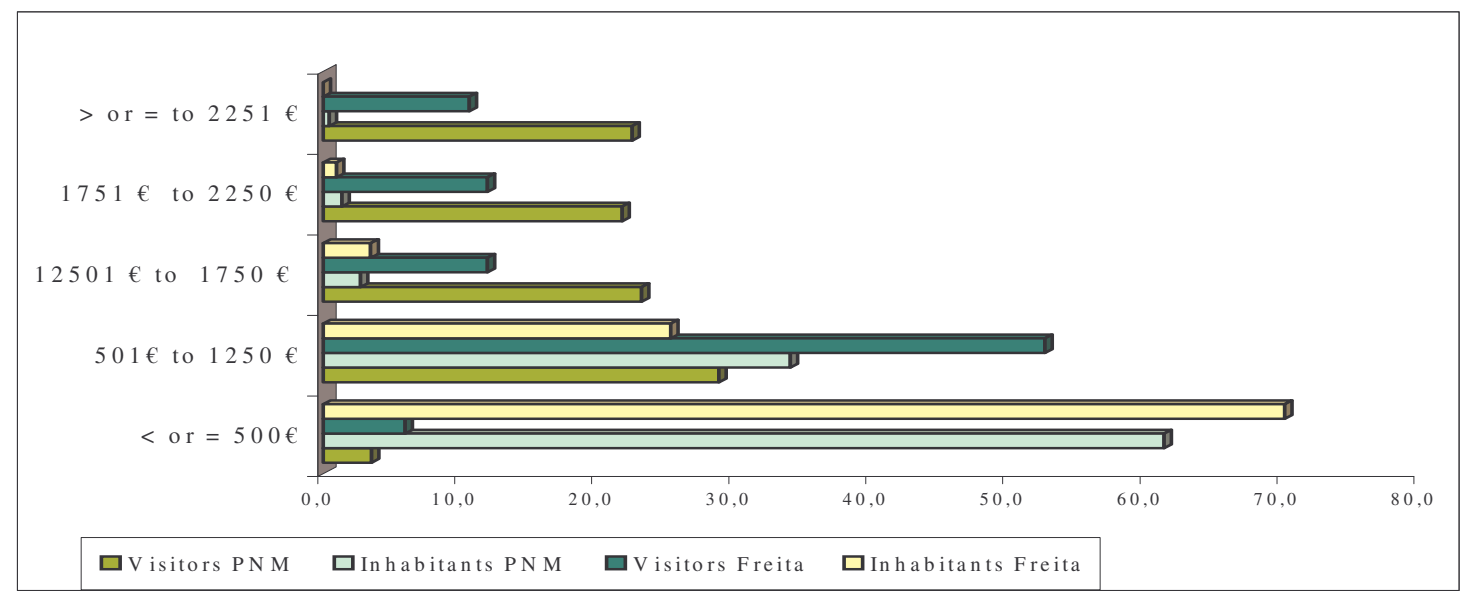

Fig 4. Income levels of residents and visitors of NPM and SF (\%)

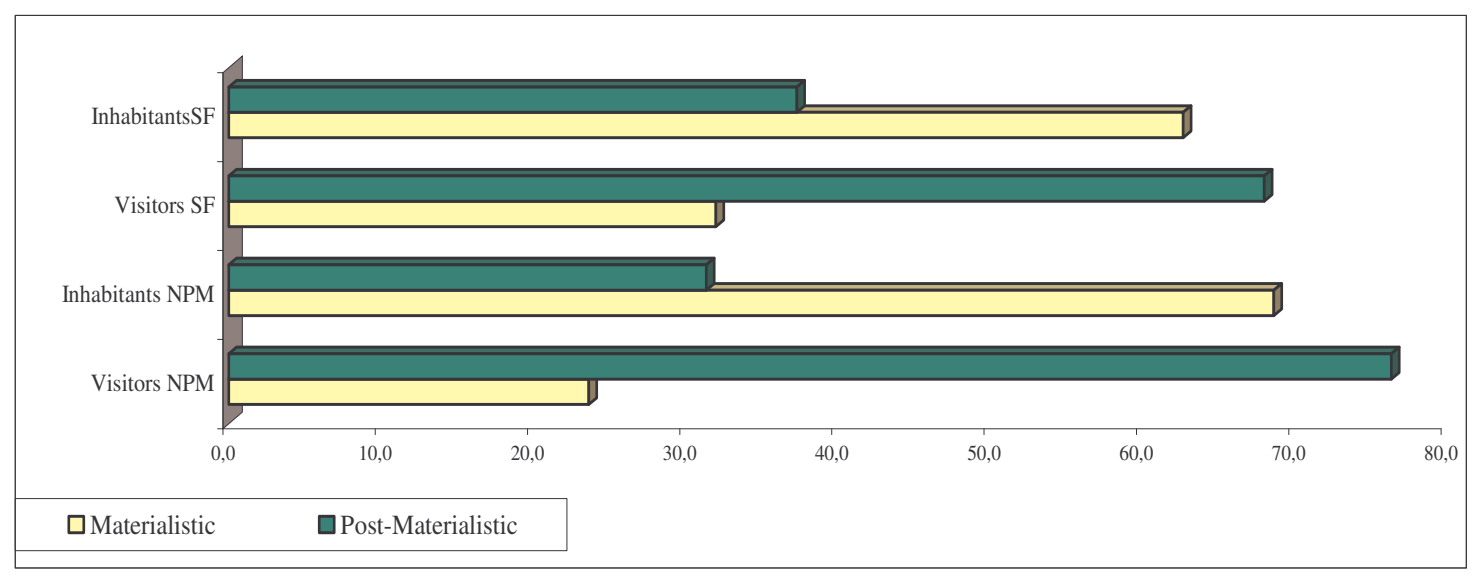

Fig 5. Materialism/Post-materialism levels of the residents and visitors of NPM and SF (\%)

\section{One Rural, Two Visions - environmental issues and images on rural areas in Portugal}

Taking into account the different socio-economic characteristics of residents and visitors inquired in both areas it can be noted that we are clearly dealing with (at least) two very distinct universes. This distinction is a decisive factor for considering the rural environment as amenity and as something to preserve. Moreover, the mentioned differences are also clear in the positions and perceptions of both categories towards the environmental regulations in force in NPM and possible to exist in SF area. In effect, as can be seen in figure 6, while most of the visitors reveal an almost total agreement with the existence and content of those norms, a very significant part of the residents demonstrate a clear disagreement with them.

The differences observed between visitors and residents in both areas are particularly evident in what concerns the regulations associated with buildings' construction or demolition, roads' 
construction, felling of trees, alterations to land morphology or the enlargement of existing farms. Two visions of rural environment and territory seem to appear - in one hand the rural space as recreational area to which regulations are fundamental in order to its preservation, on the other hand the rural space as living area to which rules and norms are consider obstacles to the everyday activities and practices of local populations. Moreover the lower levels of agreement demonstrated by the inhabitants of both areas seem to confirm the more utilitarian perspective of local populations about natural elements and resources we pointed out in the second section of the paper. Not surprisingly the NPM visitors are more in favour of regulations existence than SF visitors, since in the last case those regulations are not really in force. In any case, the statistical analysis performed (chi-square and Cramers' $V$ tests as well as Principal Component Analysis) shows a clear dichotomy between residents and visitors in this respect, and allows to conclude that visitors of both areas shared an aesthetical vision on rural environment and territory.

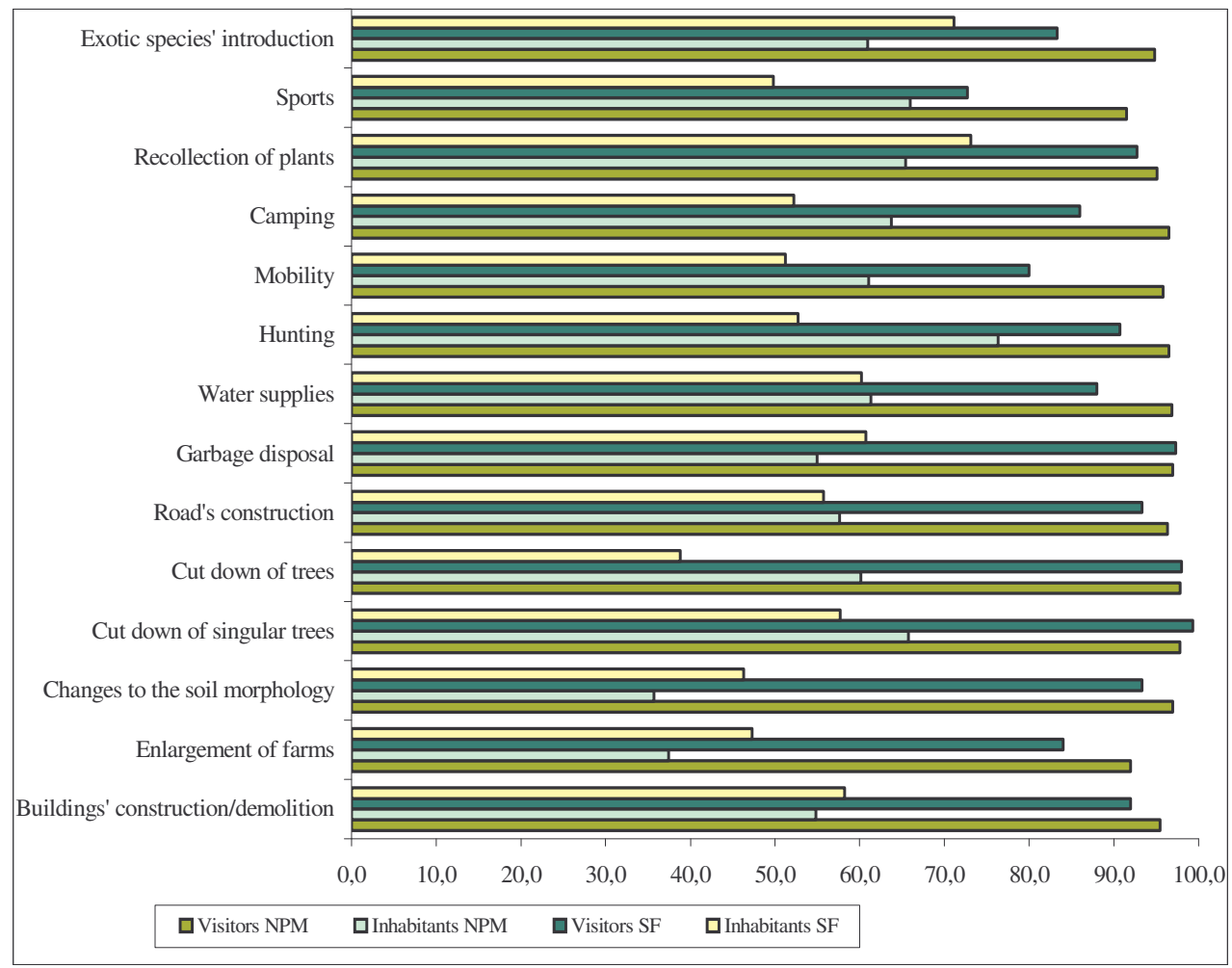

Fig 6. Visitors' and residents' agreement with some existing or possible environmental regulations in NPM and SF areas (\%)

The distinction between the two categories of respondents become more evident when we take into account the aspects or/and actions they consider more or less harmful to the environment in NPM and SF areas. As one can see in figure 7 for the majority of the referred aspects and actions a larger percentage of visitors consider them as harmful to local environment protection and conservation. Inversely the majority of the residents do not attribute to those same aspects any responsibility in degrading local environments and territories.

Once again, the dissimilarities between visitors and residents are more visible when we take into account the aspects associated to local populations' everyday activities and practices, such as construction of roads, mining, agriculture, mechanization of farming activities, planting nonautochthonous trees, architectonic degradation or alteration, hunting, fishing, killing of wild animals and also tourism. Visitors consider the aforementioned aspects harmful to local environments while residents do not perceive these aspects as negative, since they are part of their daily life and activities. The differences observed are explained not only by the diverse socio-economic characteristics of both categories of respondents, but also in the fact that for visitors rural areas represent "an escape to their everyday life contexts" (Picon, 1992). For residents, as we noted before, these areas are their everyday scenario and the support for their activities. Again the empirical evidence shows a clear opposition in the perceptions of residents 
and visitors concerning rurality and the rural environment: an aesthetical one and a utilitarian one, difficult to meet.

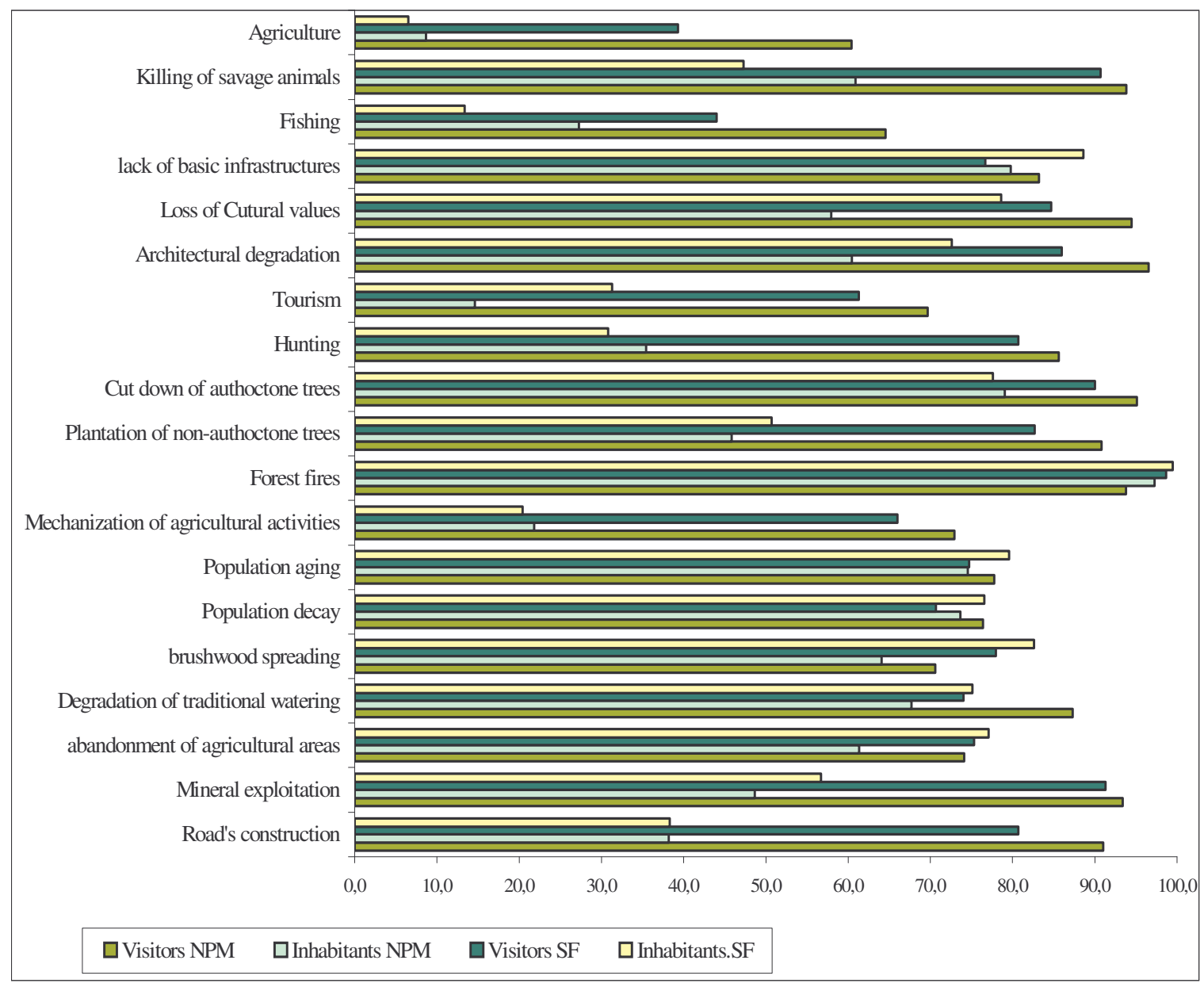

Fig 7. Aspects consider harmful, by visitors and residents, to local environment' protection and conservation in NPM and SF areas (\%)

The empirical evidence collected regarding the priority given, by both categories of respondents, to development and environmental protection measures (figure 8) emphasise the opposition between those categories. Although all the types of respondents give the main priority to the conciliation of the economic development and environmental protection aspects, the fact is that, both in NPM and SF areas, respectively $40 \%$ and $45 \%$ of the residents state that priority should be given to economic development.

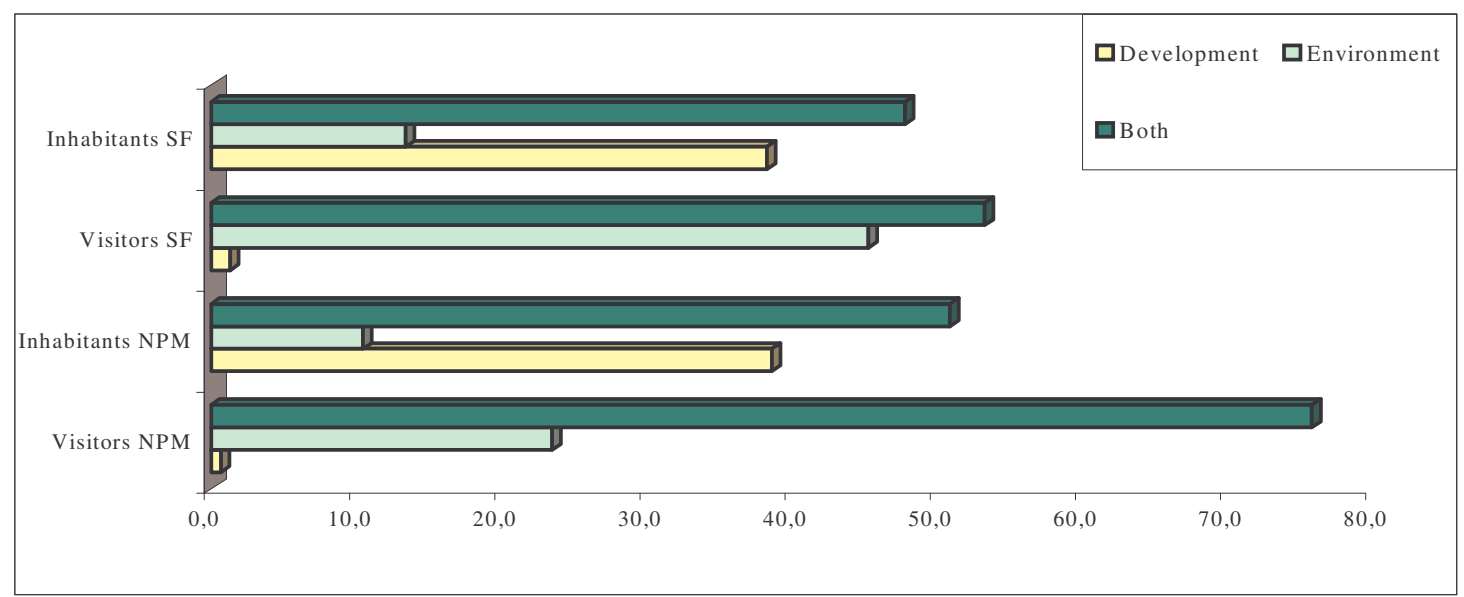

Fig 8. Priority given to economic development and environmental protection, by residents and visitors in NPM and SF areas (\%) 
The above mentioned empirical evidence confirms the fact that for visitors, rural areas are most of all demanded and consumed as natural spaces and as environmental quality reserves. In this sense rural areas are first and foremost represented by the urban populations as emptied of its economic and social activities and as non productive and lived spaces.

Concerning the perceptions about development levels one can see in figure 9 that, although the majority of respondents classify the NPM and SF areas as less developed, some differences can be pointed out in what concerns the reasons underlying the replies of both visitors and residents.

Therefore NPM visitors indicate as main reasons for the underdevelopment of the area its isolation and geographical distance to urban and more developed centres. On the other hand this type of respondents also points out as a positive consequence of the area's remoteness the existence of a harmonious integration between Man and the natural environment. NPM residents point out basically aspects related to their everyday life, such as the absence of job opportunities, the lack of diverse infrastructures and services and the local population's decline and ageing processes. In the SF case, visitors also indicate the isolation and geographical distance to main centres as reasons for the area's underdevelopment, as well as the lack of basic services and infrastructures and the rural character of this area. On the other hand, SF residents also specify aspects associated with their everyday life, such as (like NPM residents) the absence of jobs and industries, the lack of services and infrastructures as well as the population declining and ageing processes.

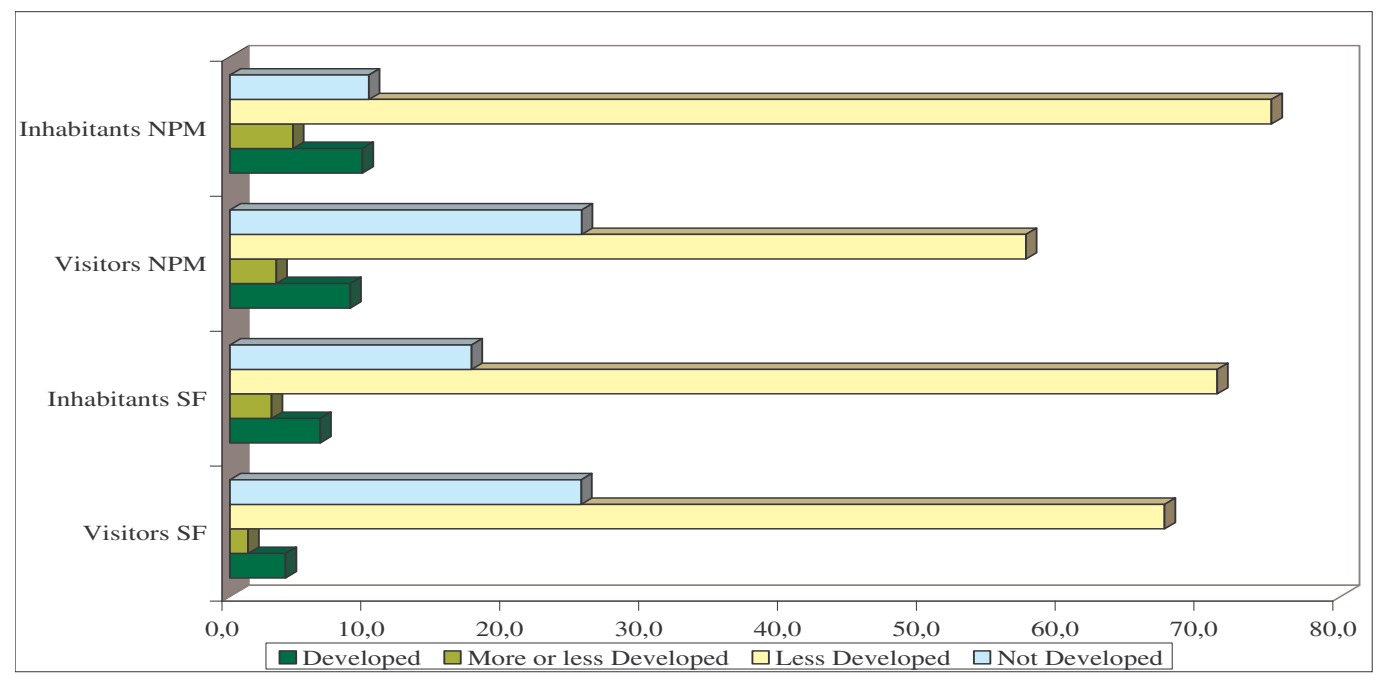

Fig 9. Perception of development levels, by residents and visitors, of NPM and SF areas (\%)

In a certain extent (although more evident in the case of NPM area than in $\mathrm{SF}^{12}$ ) one can affirm the abovementioned data reinforce what we argue in the second section of this paper, which means that there is a marked liaison between rural areas' underdevelopment and their increasing environmental symbolism, in terms of social and external representations and images on those same areas. The internal vision about development is much more related to everyday life aspects, practices and needs of local populations.

\section{Conclusion}

The theoretical discussion and the empiric evidence presented the previous sections, allow to conclude that the rural environment has been increasingly produced as symbol by urban inhabitants and also by the State. Rural areas are perceived essentially as symbols of pure nature. In this sense, rural environment tends to be represented as natural and somewhat as extra-social, in which Men, machines, animals and activities seem not to intervene. This social representation of rurality and rural areas lies beneath the motivations for its growing demand and consumption. As we have emphasized, for the residents the institution of rural areas as

${ }^{12}$ Once again, this can be explained by the legal protection status of NPM. 
amenities and as spaces to be preserved, is relatively strange, since this space is produced by them as lived, and above all, the environmental aspects as fundamental for their subsistence. In this context we advocate the emergence of a new rural-urban dichotomy. This is no longer the old dichotomy that opposed the traditional (rural) to the modern (urban) and the agricultural activities to the industrial activities, but a new opposition based on different rural and urban perceptions about rurality, rural environment as well as about economic development.

From the characteristics of both visitors and residents of NPM and SF this dichotomy is quite clear. Visitors of both areas perceived them as natural spaces, emptied of economic and social activities. Inversely, residents valued the last features as fundamental aspects to the maintenance of their practices and ways of life. Underlying these distinct representations and images there are different perceptions and valorisations of the environment. Thus, while visitors value the environmental aspects from an aesthetical point of view, residents possess a much more utilitarian perspective of those same aspects.

Taking into account the contrasting visions of visitors and residents of NPM and SF both about environment and development, one can also conclude that there is in fact a rural to live in and a rural to visit, shaped by diverse aspirations, desires and needs. As we argued before to these two visions one can add a third perspective - the one conveyed by the State through the measures and programmes for rural areas' development. This vision is, however, much more in accordance with the visitors' needs and aspirations than in conformity with the local populations' practices and requirements as well expressed, since more than a decade ago by recent national and European Union programmes and policies designed for rural development (e.g. Figueiredo, 2008a) in which the environmental and recreational aspects of rural areas are increasingly central.

It is undeniable nowadays that rural areas possess significant environmental functions, mainly for the non rural residents, but, at the same time, it is important to recognize that those functions can act as vulnerabilities concerning local populations needs and desires as well as the future of rural areas as living and dynamic spaces (e.g. Figueiredo, 2008b). It seems therefore important to question the attractiveness of a rural deprived of its real characteristics and dynamics, since it can lead to an artificialization and museification of rural areas in order to fulfill the needs of their visitors in terms of rurality and environmental quality.

References

[1] BELL, D. (1997). Anti-idyll: rural horror. In P. Cloke, \& J. Little (Eds.): Contested Countryside: Otherness, Marginalisation and Rurality (pp. 94-108). London: Routledge.

[2] BUTLER, R.H.; HALL, C.M. \& JENKINS, J.M. (1998). Introduction. In R.H Butler, C.M. Hall \& J.M. Jenkins (Eds.), Tourism and Recreation in Rural Areas (pp. 3-15). Chichester: John Willey\&Sons

[3] BUTLER, R.H. \& HALL, C.M. (1998). Image and reimaging of rural areas. In: R.H Hitler \& C.M. Hall (Eds.), Tourism and Recreation in Rural Areas (pp. 115-122). Chichester: John Willey\&Sons.

[4] CAVACO, C. (1993). O Mundo Rural em Portugal. In O Programa de Desenvolvimento Regional e o Mundo Rural. Lisbon : MPAT/MAP.

[5] CHAMBOREDON, J.C. (1980). Les usages urbains de l'espace rural: du moyen de production au lieu de recreation. Revue Française de Sociologie. 21, 97-119.

[6] COMOLET, A. (1990). Déprise agricole et avenir de l'espace rural. Futuribles. 140, 23-40.

[7] CUDWORTH, E. (2003). Environment and Society. London: Routledge.

[8] DUNLAP, R.E. \& BEUS, C.E. (1992a). Understanding public concerns about pesticides: an empirical examination. The Journal of Consumer Affairs, 26(2), 418-438. 
[9] DUNLAP, R.E. \& BEUS, C.E. (1992b). What is sustainable agriculture? An empirical examination of faculty and farmer definitions. Journal of Sustainable Agriculture, 3(1), 5-39.

[10] DUNLAP, R.E. \& BEUS, C.E. (1994). Agricultural paradigms and the pratice of agriculture. Rural Sociology, 59(4), 620-635.

[11] FIGUEIREDO, E. (2002). A rural to live, a rural to visit: visitor's and inhabitant's perceptions of the environment in two Portuguese rural areas. In Proceedings of the Fifth IFSA Symposium on Farming and Rural Systems Research and Extension - Local Identities and Globalization (pp. 272-285). Firenze: Facoltà di Agraria - Università degli Studi di Firenze/CeSAI/Instituto Agronómico per l'Oltremare.

[12] FIGUEIREDO, E. (2003). Um Rural para Viver, Outro para Visitar - o Ambiente nas Estratégias de Desenvolvimento para as Áreas Rurais. PhD Thesis, University of Aveiro, Portugal.

[13] FIGUEIREDO, E. (2008a). Imagine there's no Rural - the transformation of rural spaces into places of nature conservation in Portugal. European Urban and Regional Studies. 15(2), 159-171.

[14] FIGUEIREDO, E. (2008b). ¿Cómo Proteger a las Personas en las Áreas Protegidas? El medio ambiente como vulnerabilidad en dos áreas protegidas portuguesas. Revista Española de Estudios Agrosociales y Pesqueros, (in press).

[15] GILG, A. (1991). Countryside Planning Policies for the 1990's. Wallingford: CAB International.

[16] HALFACREE, K. (1993). Locality and social representation: space, discourse and alternative definitions of the rural. Journal of Rural Studies. 9, 1-15.

[17] HALFACREE, K. (1995). Talking about rurality: social representations of the rural as expressed by residents of six English parishes. Journal of Rural Studies. 11, 1-20.

[18] HALFACREE, K. (1997). Contrasting roles for the post-productivist countryside: a postmodern perspective on counterurbanisation. In P. Cloke \& J. Little (Eds.), Contested countryside: otherness, marginalisation and rurality (pp. 109-122). London: Routledge.

[19] JOLLIVET, M. (1994). Bilan des Recherches en Sciences Sociales sur les Problemes d'Environnement en Millieu Rural dans les Pays Européens. Paris: CNRS (LDSRE).

[20] JOLLIVET, M. (1997b). Les métamorphoses d'un rural incertain. In M. Jollivet (Ed.), Vers un Rural Postindustriel - Rural et Environnement en Huit Pays Européens (pp. 351-371). Paris: L'Harmattan.

[21] KAYSER, B. (1990). La Renaissance Rural - Sociologies des Campagnes du Monde Occidental. Paris : Armand Colin,

[22] KING, R. (1992). Heterogeneity of rural areas: posing the strategic issues. In M. O'Cinneide \& M. Cuddy (Eds.), Perspectives on Rural Development in Advanced Economies (pp. 3750). Galway: University College.

[23] LOWE, P. (1992). Industrial agriculture and environmental regulation. Sociologia Ruralis. 32(1), 4-10.

[24] LUGINBUHL, Y. (1991). Le paysage rural. Études Rurales. 121-124, $27-44$.

[25] MACNAGHTEN, P. \& URRY, J. (1998). Contested natures. London: Sage.

[26] MATHIEU, N. \& JOLLIVET, M. (1989). De la question de la nature à la question de l'environnement - réperes anciens pour des questions nouvelles. In N. Mathieu \& M. Jollivet (Eds.), Du Rural à l'Environnement - La Question de la Nature Aujourd'hui (pp. 11-22) Paris: l'Harmattan.

[27] MELO, A. (1992). Education and training for rural development. In M. O'Cinneide \& M. Cudy (Eds.), Perspectives on Rural Development in Advanced Economies (pp. 199-208). Galway: University College. 
[28] MORMONT, M. (1990). Who is rural? Or how to be rural? Towards a sociology of the rural. In T. MARSDEN et al, Rural Restructuring - Global Processes and Their Responses pp.2144. London: David Fulton.

[29] MORMONT, M. (1994a). La agricultura en el espacio rural europeo. Agricultura y Sociedad. 71, 17-49.

[30] MORMONT, M. (1994b). La place de l'environnement dans les strategies de developpement rural en Europe. Territoires d'Europe, Vol. II - Elements Fonctionnels de Strategies Regionales en Faveur du Monde Rural (pp. 135-155). Brest: CEDRE.

[31] NEWBY, H. (1985). The Green and Pleasant Land? - Social Change in Rural England. London: Wildwood House.

[32] PERNET, F. (1994). Le système rural localisé comme outil des politiques regionales. Territoires d'Europe - Vol. II - Elements Fonctionnels de Strategies Regionales en Faveur du Monde Rural (pp. 157-172). Brest: CEDRE.

[33] PHILLIPS, M., FISH, R. \& AGG, J. (2001): Putting together ruralities: towards a symbolic analysis of rurality in the British mass media. Journal of Rural Studies, 17, 1-21.

[34] PINET, J-M. (1984). Risques liées aux activités agricoles. In J. THEYS, J. (Ed.), Les Politique de l'Environnement face à la Crise (pp. 86-97). Paris: Germes,.

[35] RAMOS-REAL, E. (1995). De la crisis a la regeneracion rural. In Actas do III Colóquio Hispano-Português de Estudos Rurais (pp. 125-149). Lisbon: SPER.

[36] SAINTENY, G. (1992). La crise du monde rural, la nature et l'impôt. Futuribles, 170, 21-39.

[37] SHUCKSMITH, M. et al. (2006). First European Quality of Life Survey: Urban-rural Differences. Luxembourg: Office for Official Publications of the European Communities.

[38] The Future of Rural Society (1988). Bulletin of the European Communities, 4/88, Brussels.

[39] WOODS, M. (2003). Conflicting environmental visions of the rural: windfarm development in Mid Wales. Sociologia Ruralis, 43(3), 271-288. 